\title{
Effect of Banana Homogenate on Shoot Regeneration of Ciplukan (Physalis angulata L.)
}

\author{
Varni Apensa, Retno Mastuti*
}

Department of Biology, Faculty of Mathematics and Natural Sciences, University of Brawijaya, Malang, Indonesia

In vitro culture techniques can be used as an alternative problem solving in an effort to provide Ciplukan plant as a raw material of herbal medicine in a sustainable manner. The purpose of this study was to observe the effect of banana homogenate $(\mathrm{BH})$ added into culture medium on shoot regeneration of Ciplukan (Physalis angulata L.) and plantlet development until acclimatization stage. The experimental design used was a randomized factorial group. The first factor was the two varieties of banana fruit namely, Ambon and Raja. The second factor was concentration of BH with four levels, 0 (control), 2.5\%, 5\% and $7.5 \%$ and each treatment combination was repeated five times. Explant used in this research was the third node of 2 weeks old in vitro shoot after subculture to MSO medium. Data analysis used ANOVA test. Eight week after culture (WAC) medium containing $\mathrm{BH}$ induced higher number of shoot compare to medium without $\mathrm{BH}$. The addition of $5 \% \mathrm{BH}$ var. Ambon had significant effect on increasing shoot number. Well rooted plantlets produced in MSO rooting medium also showed high survival rate $(66.7 \%<-100 \%)$ two weeks after transferred to greenhouse. Therefore, the addition of $\mathrm{BH}$ into in vitro medium can be an alternative method for micropropagation of Ciplukan.

Keywords: Banana homogenate, Ciplukan, micropropagation, nodal explants.

\section{INTRODUCTION}

Ciplukan (Physalis angulata L.) is a wild plant species that will be commonly found especially on the edge of the forest, yard, and corn fields. Ciplukan has been widely used as traditional medicine [1]. Clinically, this plant is proven to have a lot of bioactive content. Ciplukan can be used as antihyperglycemic, antibacterial, antiviral, immunostimulant and immunosuppressant (immunomodulator), antiinflamation, antioxidant, analgesic, and cytotoxic. Also as diuretic, neutralize toxins, relieve cough, and activate the function of the body glands and anti-tumor. Ciplukan fruit can also be used to cure bleeding gums [2]. Currently, Ciplukan already widely used by the industry as herbal medicine. Therefore, to meet the needs of the industry, the demand for Ciplukan supply is increasing [3].

The increasing demand for medicinal plants causes over extraction from the wild source. Even though, the medicinal plants that obtained from various locations will have varies in productivity. Some environmental factors may affect all phases of growth and development [4] including biosynthesis of secondary metabolites.

\footnotetext{
* Correspondence address:

Retno Mastuti

Email : mastuti7@ub.ac.id

Address: Dept. Biology, Faculty of Mathematics and Natural Science, University of Brawijaya, Veteran Malang, Malang 65145.
}

To prevent the supply of medicinal plants from natural source which has various characters it should be accompanied by the availability of standardized source. In vitro tissue culture techniques can be used as an alternative problem solving in an effort to provide the plant as a sustainable raw material for herbal medicine. Largescale plant tissue or organ culture for the production of secondary metabolites is an attractive alternative approach to traditional methods of cultivation of medicinal plants [5]. The advantages of this method are many; it is independent of soil, climatic interference, geographical location, does not require a very wide area for produce large quantities of plants at relatively narrow space [6] and it can provide a continuous and reliable source of natural products. The success of tissue culture techniques is influenced by several factors, including the composition of plant growing media $[7,8]$. Culture media frequently used for tissue culture techniques is $\mathrm{Mu}$ rashige and Skoog (MS) basal medium (1962). MS medium is widely used for tissue culture of most plant tissues as its balanced composition over other media. This basal medium contains complete macro nutrients ( $N, P, K, C a, M g$, and $\mathrm{Na}$ ) and micro ( $B, C o, M n, I, F e, Z n$, and $\mathrm{Cu}$ ). MS medium also contains other energy sources such as sugar, vitamins, amino acids and myo inositol [9].

In vitro culture media can also be added by complex organic matter as a source of sugar, vitamins, plant growth regulators and amino acids. 
Natural organic compounds that have been widely used include coconut water, yeast extract, malt extract, potato extract, papaya extract, banana porridge (banana homogenate), tomato juice and wotel juice. The use of such organic organic compounds as additives to media can provide better growth and morphogenesis [10].

Bananas are commonly added to in vitro media in the form of slurry or homogenate. Banana homogenate $(\mathrm{BH})$ has been able to increase the number of shoots of various orchids [11-16]. Provision of $\mathrm{BH}$ can improve regeneration response, number of shoots per explant and complete plantlet on Cymbidium pendulum compared to without addition of banana pulp [15]. Addition of 150 g. $\mathrm{L}^{-1}$ banana var Ambon and NAA 20 ppm can produce the highest average number of shoots on black orchid plant (Coelogyne pandurata) [17]. Bananas contain carbohydrates, proteins, fats, $\mathrm{Ca}, \mathrm{P}, \mathrm{Fe}$, vitamin $\mathrm{A}$, vitamin $\mathrm{B}-1$, and vitamin $\mathrm{C}$ so it can help the regeneration process in plants [18]. Some types of bananas, ie banana var. Kepok, Mas, Raja, Ambon Lumut and Ambon Putih can produce different in vitro growth response on Phalaenopsis orchid planlet [19]. Banana var. Raja and Ambon were able to increased shoot number, plantlet height, leaf length and number and root number of orchids $[20,21]$. Therefore, in this study the influence of two local varieties of banana, namely Ambon and Raja on shoot regeneration and plantlet development of Ciplukan nodes explant was observed.

\section{MATERIAL AND METHOD \\ Preparation of source explant}

The ripe yellow Ciplukan fruit was split and seeds were taken and dried for 2-3 days. Dry seeds were germinated on agar medium (12 g. $\mathrm{L}^{-1}$ ) without addition of growth regulator under 500 lux light intensity at $23 \pm 2{ }^{\circ} \mathrm{C}$. Cotyledon and shoot apical were excised from two weeks old seedling then subcultured into hormone free MS (MSO) medium. The nodal explants were taken from the third node of growing shoots.

\section{In vitro culture medium}

Shoot induction medium (SIM) used in this study was $M S$ basal salt medium + growth regulator (BAP 2 mg. $\mathrm{L}^{-1}+$ IAA $0.05 \mathrm{mg} \cdot \mathrm{L}^{-1}$ ) + banana homogenate $(\mathrm{BH})$ supplemented with 30 g. $\mathrm{L}^{-1}$ commercial granulated sugar. The effect of two local banana varieties, Ambon and Raja were observed in this study. Four concentrations for each banana, var. Ambon (PA) and Raja (PR), were $0,2.5 \%, 5.0 \%$ and $7.5 \%(\mathrm{w} / \mathrm{v})$. Banana homogenate were derived from finely ground rip- ened fruit shortly prior to add into the medium. After stirring evenly the medium solution was adjusted to $\mathrm{pH} 5.8$ and solidified by $12 \mathrm{~g} . \mathrm{L}^{-1}$ agar. There were two types root induction medium (RIM), ie 1) MSO without growth regulator, and 2) $\mathrm{MS}+$ auxin (NAA $2 \mathrm{mg} \cdot \mathrm{L}^{-1}+\mathrm{IBA} 1 \mathrm{mg} \cdot \mathrm{L}^{-1}$ ). Culture medium was sterilized by autoclaving at $121^{\circ} \mathrm{C}$, 1.5 atm for 15 minutes.

\section{Shoot induction and multiplication}

Three nodal explants were inoculated on each bottle of SIM without $\mathrm{BH}$ as control (PO) or with $\mathrm{BH}$ (PA and PR) with five replicates to observe their capability of shoot induction and multiplication. The cultures were incubated in culture room at $24 \pm 2{ }^{\circ} \mathrm{C}$ under 500 lux light intensity for 24 hours. The number and height of shoots and the leaf number were measured eight week after culture (WAC). The shoot height was measured from the base of the shoots on the surface of the culture medium to the shoot tip.

\section{Root induction and plantlet regeneration}

The eight-week-old shoots induced in P0, PA and PR mediums were subcultured on two types root medium, ie MSO and MS + auxin. The cultures were incubated in culture room at $24 \pm 2^{\circ} \mathrm{C}$ under 500 lux light intensity for 24 hours. The number and length of roots in each shoot, plantlet height, leaf number and fresh weight (FW) of plantlets on MSO medium and MS + auxin medium were measured one and three WAC, respectively.

\section{Acclimatization}

Plantlets with well developed root were removed from rooting medium. The root part was thoroughly washed with running water to remove the agar medium. The plantlet was then grown on a plastic cup ( $240 \mathrm{ml}$ in size) containing a mixture of soil, compost and husk (ratio 1: 1: 1) and enclosed with transparent plastic for two weeks. Subsequently, the plants were moved to pots $(\phi 17 \mathrm{~cm})$ with the same medium composition and placed in the green house for two weeks.

\section{Experimental Design and Data Analysis}

The results are presented as mean \pm SD (standard deviation). Data analysis using ANOVA (Analysis of Variance) test to determine whether there is difference of influence between type and concentration of banana var. Ambon and Raja for all parameters observed. 


\section{RESULT AND DISCUSSION \\ Shoot Regeneration}

The occurrences of green spots were noticed on the surface of nodal tissues two or three days of culture. The formation of green spots is positively correlated with shoot regeneration $[22,23]$. One WAC green leaves were observed in the medium with (Fig. $1 \mathrm{~B}-\mathrm{C}$ ) and without $\mathrm{BH}$ addition (Fig. 1A).

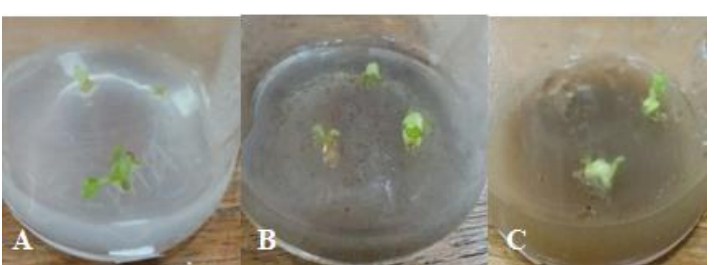

Figure 1. Shoot with green leaf 1 WAC. (A) PO (control) medium, (B) PA medium, (C) PR medium.

Eight WAC shoot on PO (control) medium (Figure 2A) had stems thicker and leaves smaller than in PA and PR medium. The PA medium produced more shoots and leaves number but had a shorter shoot height (Figure 2B) than the control and PR medium (Figure 2C). Banana has been frequently added as organic additive in in vitro culture because it is a good source of mineral, vitamin and natural plant growth regulators like IAA, gibberellin and zeatin $[24,25]$. Banana is also rich in carbohydrates that act as carbon source which supply energy to the heterotroph plant during the early stage in vitro culture $[26,27]$.

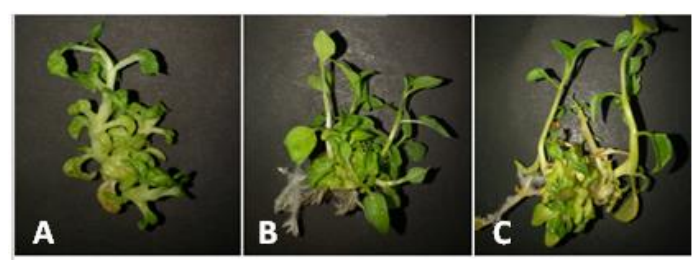

Figure 2. Shoot multiplication 8 WAC. (A) PO (control) medium, (B) PA medium, (C) PR medium.

Medium containing either $\mathrm{BH}$ cultivars 'Ambon' (PA) or 'Raja' (PR) induced higher number of shoot $(3.25 \pm 1.29$ or $3.33 \pm 1.23$ ) (Fig. $3 \mathrm{~A})$ than the medium without addition of $\mathrm{BH}$ $(1.75 \pm 0.5)$ eight WAC. Conversely, the height of shoots (Fig. 3B) and the number of leaves (Fig. $3 \mathrm{C}$ ) produced in medium containing $\mathrm{BH}$ tends to decrease compared to those produced in control medium. High frequency of shoot number is a prerequisite for clonal propagation [8]. However, increase the number of shoot usually accompanied by decrease the shoot length [28].

Eight week after culture only $5 \% \mathrm{BH}$ produced significantly high number of shoots while in other parameters were not significant effect (Fig. 4). The sucrose content in banana has a role in enhancing in vitro regeneration [14]. Medium containing $5 \% \mathrm{BH}$ was also induced the highest regeneration frequency of Cymbidium pendulum [10]. The positive effect of $5 \% \mathrm{BH}$ on enhancing shoot number is advantageous to provide the $P$. angulata plant as a raw material for herbal medicine.

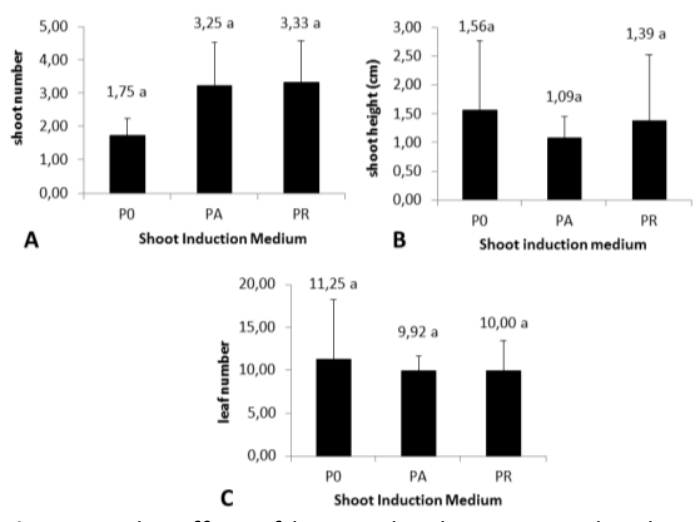

Figure 3. The effect of banana local variety to the shoot growth 8 WAC. (A) Shoot number, (B) Shoot length, (C) Leaf number. Note: the same letter on different shoot induction medium showed no significant difference in ANOVA test $(a=$ 0.05).

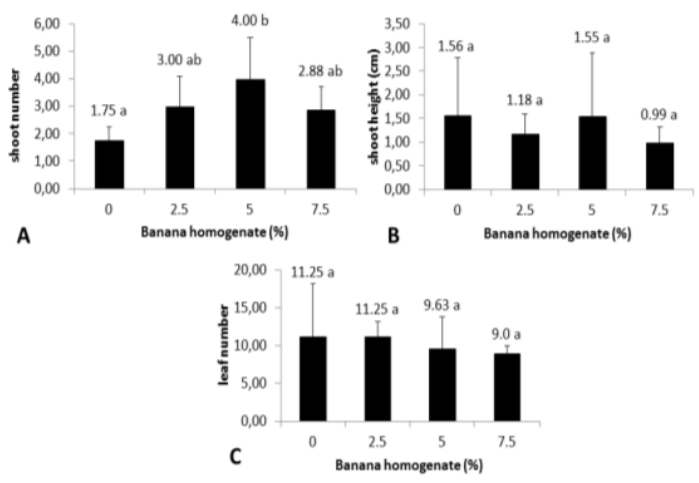

Figure 4. The effect of $\mathrm{BH}$ concentration in shoot induction medium to the shoot growth 8 weeks after culture. (A) Shoot number, (B) Shoot length, (C) Leaf number. Note: the same letter on different concentration of $\mathrm{BH}$ showed no significant difference in ANOVA test $(a=0.05)$.

\section{Root Induction and Plantlet Regeneration}

MS free hormone medium was able to induce roots one WAC. Meanwhile in MS + auxin medium the roots were induced three weeks after subculture. MS free hormone medium produced white, long and thick roots (Fig. 5A-C). While MS + auxin medium produced small fibers, short, thin and brownish white roots (Fig. 5D-F). This is consistent with the research of [29] which showed that roots produced in MS + auxin were short, thin and fragile. Auxin at low concentra- 
tions increase root length while at high concentrations can inhibit root growth [30]. This results show that the auxin added to the root induction medium actually inhibits root growth. Thickened roots of Carica papaya L. with few lateral branches and no root hairs were making them difficult to acclimatize [31].

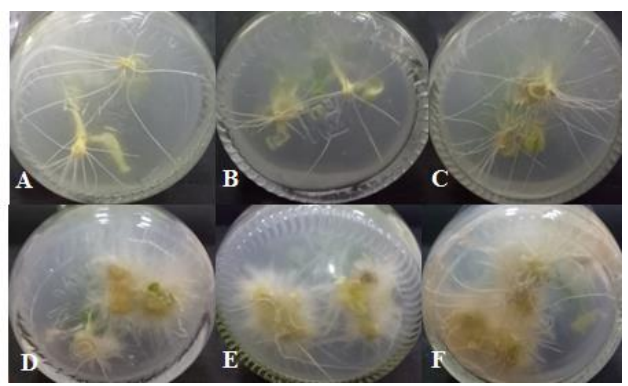

Figure 5. Roots formed from P. angulata shoots on MSO medium ( 1 week old) and MS + auxin medium (3 weeks old). A \& D. PO (control) medium. B \& E. PA Medium. C \& F. PR Medium. A - C MSO medium. D-F MS + auxin medium.
Plantlets with normal leaf was observed on MSO medium (Fig. 6A) whereas the plantlet on MS + auxin medium showed curved leaf edge (Fig. 6B). Abnormal leaves in maize [32], bean and Arabidopsis [33] have been reported in medium with high concentration of auxin.
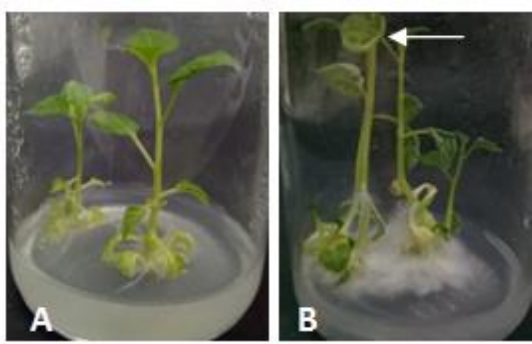

Figure 6. Planlet $P$. angulata on rooting medium. (A) planlet on MSO medium (1 WAC), (B) planlet on MS + auxin medium (3 WAC).
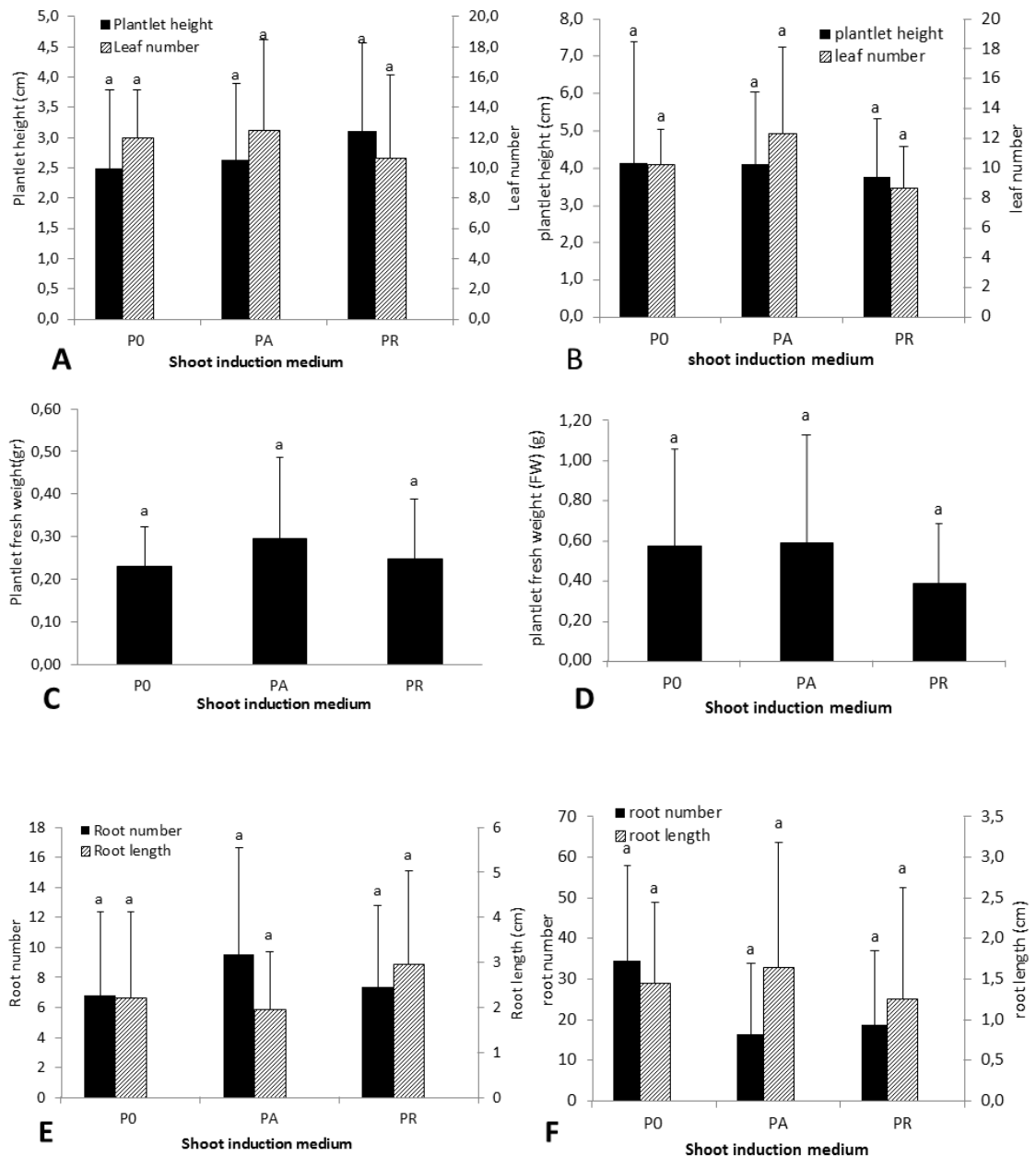

Figure 7. Effect of banana homogenate added in SIM on plantlet growth in MSO and MS + auxin rooting medium. A. Plantlet height and leaf number in MSO rooting medium, B. Plantlet height and leaf number in MS + auxin rooting medium, C. Plantlet FW in MSO rooting medium, D. Plantlet FW in MS + auxin rooting medium, E. Root number and root length in MSO rooting medium, F. Root number and root length in MS + auxin rooting medium. 

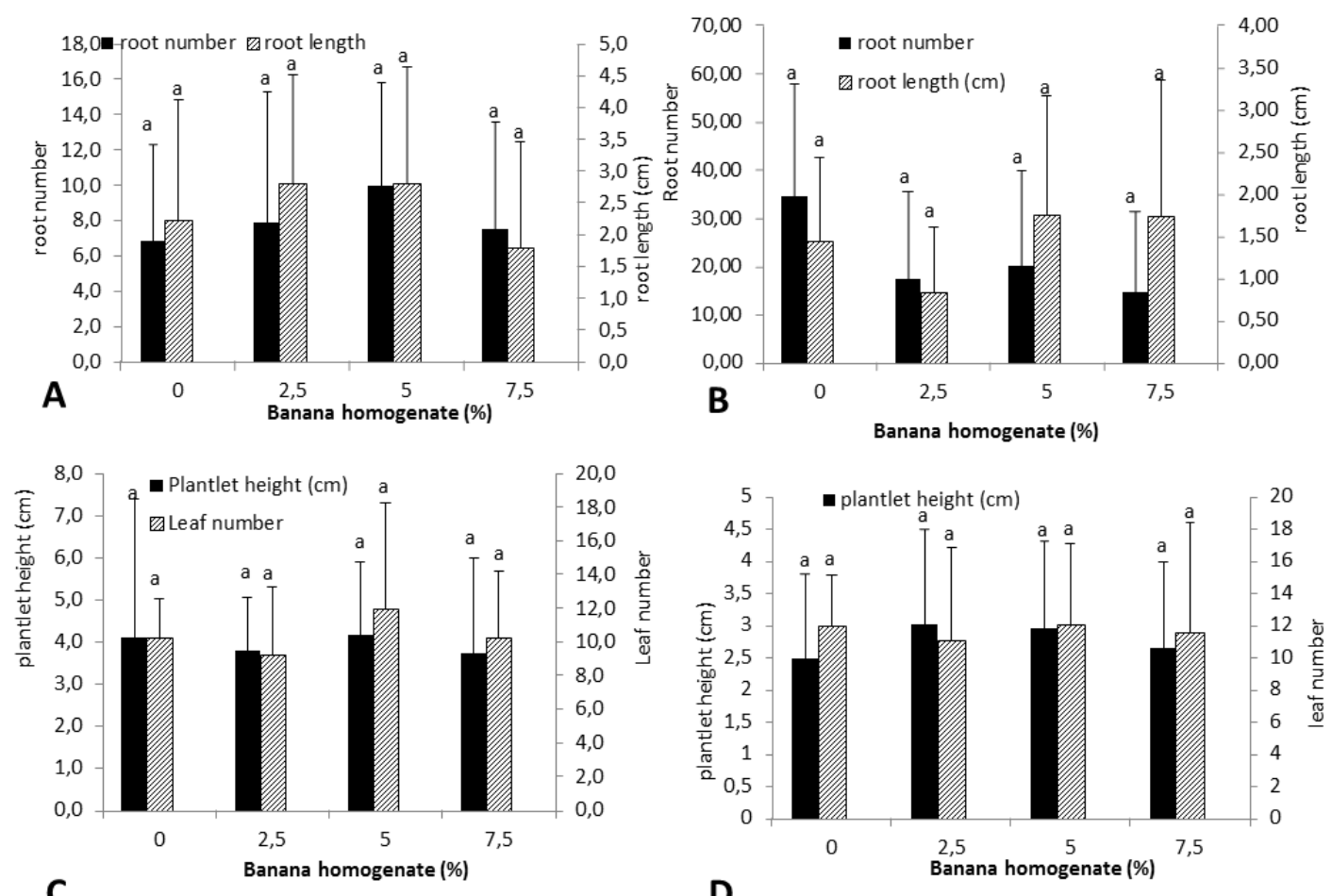

C

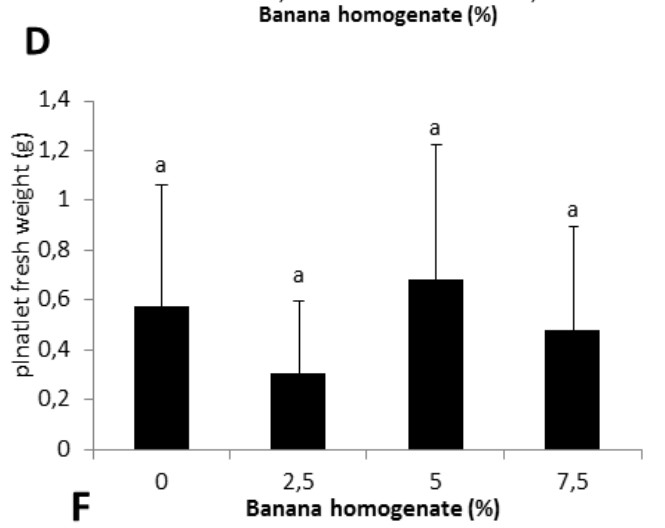

Figure 8. Effect of banana homogenate concentration added in SIM on plantlet growth in MSO and MS + auxin rooting medium. A. Root number and root length in MSO rooting medium, B. Root number and root length in MS + auxin rooting medium C. Plantlet height and leaf number in MSO rooting medium, D. Plantlet height and leaf number in MS + auxin rooting medium Root number and root length in MSO rooting medium E. Plantlet fresh weight in MSO rooting medium, F. Plantlet fresh weight in MS + auxin rooting medium.

Shoot derived from PA medium showed better responses in almost all parameters studied (Fig. 7A-D) except for root number in MSO medium (Fig. 7E) and root length in MS + auxin medium (Fig. 7F). As shown in Fig. 3A the shoot number induced in SIM medium containing $\mathrm{BH}$ especially PA medium (var. Ambon) was comparatively higher than PO control medium. The addition of $\mathrm{BH}$ derived from var. Ambon can increase plantlet height, leaf number and root length of Dendrobium plantlet [34]. In this study high number of regenerated shoot in SIM produced high number of the sites of auxin synthesis. Consequently, the content of auxin endogenous hormone in plantlet increased. This results shows that BH supplements in SIM still influence plantlet growth in rooting medium.

In MSO rooting medium shoot derived from SIM containing 2.5 and $5 \% \mathrm{BH}$ tended to produce number and length of roots (Fig. 8A), height of plantlet (Fig. 8C) and fresh weight of plantlet (Fig. $8 \mathrm{E})$ higher than shoots derived from $0 \%$ (control) and SIM containing $7.5 \% \mathrm{BH}$. However, in MS + auxin rooting medium the shoots derived from SIM medium containing 5\% BH tended to produced higher root length $(1.7 \pm 1.4 \mathrm{~cm}$ ) (Fig. $8 B)$, plantlet height $(4.2 \pm 1.7 \mathrm{~cm})$, number of leaves (12.0 \pm 6.3$)$ (Fig. 8D) and fresh weight of plantlet $(0.7 \pm 0.5 \mathrm{~g})$ (Fig. 8F). The number and length of roots, number and length of leaves of new $D$. lasianthera will increase with the addition 
of high concentration of $\mathrm{BH}$, ie 150 g. $\mathrm{L}^{-1}(15 \%)$ [35). This shows that regeneration of $P$. angulata plantlet could be induced with low concentrations of $\mathrm{BH}$.

In this study banana var. Ambon and Raja added in SIM and all concentration tested did not significantly affect all parameters studied for ciplukan in both of MSO and MS + auxin rooting medium. This is consistent with previous study [36] who stated that $\mathrm{BH}(2.5 \%, 5.0 \%$ and $7.5 \%$ $\mathrm{v} / \mathrm{v}$ ) did not significantly promote rooting of Dimorphorchis lowii. It was assumed that root formation required organic nitrogen compunds since the best performance of root regeneration was observed in culture media supplemented by coconut water, pepton and yeast [36].

In this study the difference in root number and morphology is more due to the presence or absence of growth hormone in culture medium (MSO and MS +auxin). Auxin is an essential factor for induction of roots in plants. Adventitious roots produced in MSO medium promoted by basipetal auxin transport from shoot tip toward the basal parts. Addition of exogenous auxin in rooting medium will increased its concentration in cellular level [37]. In this study high accumulation of auxin promoted more root number but might inhibited root elongation.

\section{Acclimatization}

Plantlets derived from SIM supplemented with $\mathrm{BH}$ can grow well in the early adaptation stage (Fig. 9). No significant different in all parameters was observed two weeks after transferred the plantlets to plastic glass.

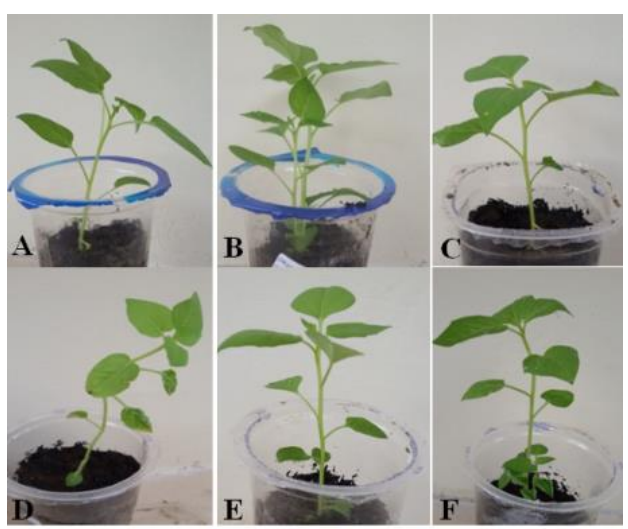

Figure 9. Plant growth in acclimatization stage 2 weeks after planting. A, D. PO medium (control), B, E. PA medium, CF. PR medium. A-C. medium MSO, and D-F. medium MS + auxin.

After being transferred to pot in greenhouse for 2 weeks the plantlets derived from MSO rooting medium had better survival compared to the plantlets derived from MS + auxin rooting medium. The plant from PO medium had the lowest survival rate (33.3\%) compared to the plant from SIM containing BH (66.7 - 100\%) (Table 1). Whereas, in MS + auxin rooting medium the plantlets with survival rate $100 \%$ was only obtained from $2.5 \%$ and $7.5 \% \mathrm{PR}$ medium. Survival rate of plant from other SIM was only $50 \%$.

Table 1. Survival rate of $P$. angulata plantlet after 2 weeks grown in the greenhouse

\begin{tabular}{|c|c|c|}
\hline \multirow[b]{2}{*}{$\begin{array}{l}\text { Shoot induc- } \\
\text { tion medium }\end{array}$} & \multicolumn{2}{|c|}{ Survival rate of plantlets (\%) } \\
\hline & MSO & $\begin{array}{c}\mathrm{MS}+\mathrm{NAA} 2 \mathrm{mg} \cdot \mathrm{L}^{-1}+ \\
\text { IBA } 1 \mathrm{mg} \cdot \mathrm{L}^{-1}\end{array}$ \\
\hline P0 (control)*) & 33.30 & 50 \\
\hline PA 2.5 & 100 & 50 \\
\hline PA 5 & 100 & 50 \\
\hline PA 7.5 & 66.7 & 50 \\
\hline PR 2.5 & 100 & 100 \\
\hline PR 5 & 100 & 50 \\
\hline PR 7.5 & 83.3 & 100 \\
\hline
\end{tabular}

Note: ${ }^{*}$ ): P0 (control)= without banana homogenate; PA: Banana var. "Ambon" ; PR: Banana var. "Raja"

After transferred to pot the plants derived from PA and PR medium for shoot induction and either MSO or MS + auxin for rooting medium (Fig. 10B,E) remain had higher plant height and wider leaves than the plants derived from other mediums (Fig. 10A,D,C,F). While plants derived from PO (control) medium and MS + auxin rooting medium have a narrower leaves than plants derived from MSO rooting medium. Short thin root produced in MS + auxin rooting medium. The smooth and short roots appear to be less able to facilitate the absorption of water and minerals from the medium to support the growth of the vegetative organ.

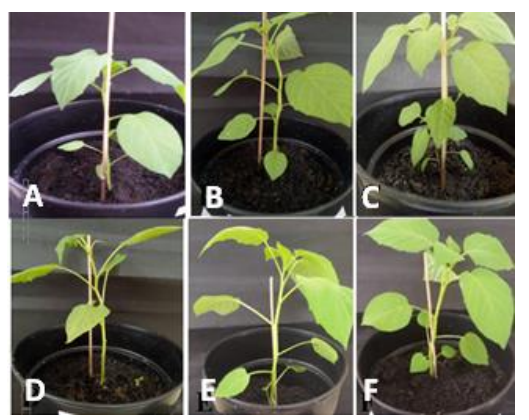

Figure 10. Acclimatization of in vitro micropropagation of $P$. angulata two weeks after transfer. A,D. P0 (control) medium; B,E. PA medium; C,F. PR medium; $A, B, C$. MSO medium; $D, E, F . M S+$ auxin medium.

Naturally, regeneration of adventitious organs depends on endogenous hormones [38]. Endogenous auxin is of primary importance initiating adventitious root formation [39]. This sug- 
gests that the MSO medium without hormones is capable for developing a functional root system. In vitro roots still functional and continue to grow during acclimatization (40). Therefore, formation of functional root system in in vitro plantlet is to be important step to survive after transplantation [41]. High survival of plants from MSO rooting medium indicates that endogenous auxin of $P$. angulata plantlet has been able to produce good functional root system. Functional root system can absorb nutrients and water from acclimatization media in a good way thereby enhancing the growth of the plant.

\section{CONCLUSION}

Applications of $5 \% \mathrm{BH}$ as supplement in tissue culture media should be considered due to positive response in shoot regeneration and multiplication of $P$. angulata. High survival rate $(66.7 \%<-100 \%)$ of plant in aclimatization stage after transferred to pot in greenhouse due to better rooting system in MSO rooting medium. This condition support the sustainability of raw materials of herbal medicine.

\section{REFERENCES}

[1] Mahalakshmi, A.M., B. Ramesh, Nidavani. 2014. Physalis angulata L.: an Ethanopharmacological review. J. Pharm. Res. 4(3). 1479-1486.

[2] Santoso, H.B. 2008. Ragam dan khasiat tanaman obat. Agromedia Pustaka. Jakarta.

[3] Sukmadjaja, D., I. Mariska. 2003. Perbanyakan bibit Jati melalui kultur jaringan. Research Center of Biotechnology and Agriculture Genetic Resources. Bogor.

[4] Haferkamp, M.R. 1988. Environmental factors affecting plant productivity. In: White, R.S., R.E. Short (Eds). Fort Keogh Research Symposium. Montana Agr. Exp. Sta. Bozeman, Miles City. 27-36.

[5] Alamgir, A.N.M. 2017. Cultivation of herbal drugs, biotechnology, and In Vitro production of secondary metabolites, high-value medicinal plants, herbal wealth, and herbal trade. In: Therapeutic Use of Medicinal Plants and Their Extracts: Volume 1. Progress in Drug Research, Vol 73. Springer. Cham.

[6] Sharma, A., V. Agrawal. 2012. Tissue culture aspects of ornamental plants. J. Biotechnol. 1(1). 2319-3859.

[7] George, E.F., M.A. Hall, G.J.D. Klerk. 2008. Plant propagation by tissue culture, $3^{\text {rd }}$ Ed. Springer. Netherland.
[8] Yildiz, M. 2012. The prerequisite of the success in plant tissue culture: high frequency shoot regeneration. In: Leva, A., L.M.R. Rinaldi (Eds). Recent Advances in plant In Vitro culture. InTech. DOI: 10.5772/51097.

[9] Sudipta, K.M., S.M. Kumara, M. Anuradha. 2013. Influence of various carbon sources and organic additives on in vitro growth and morphogenesis of Leptadenia reticulata (Wight \& Arn), A valuable medicinal plant of India. J. Pharm. Sci. 21(2). 174-179.

[10] Molnar, Z., E. Virag, V. Ordog. 2011. Natural substances in tissue culture media of higher plants. Article Acta Biologica Szegediensis. 55(1). 123-127.

[11] Sudeep, R., P.K. Rajeevan, P.K. Valasalakumari, C. K. Geetha, 1997. Influence of organic supplements on shoot proliferation in Dendrobium. J. Hortic. 3. 38-44.

[12] Ngampanya B., W. Homlaaor. 2010. Simple media for Dendrobium orchid seed germination and protocorm development. Acta hortic. 878. 219-223.

[13] Lekha, R.C., C. Vidya, K. Rajmohan, S.T. Mercy. 2005. Protocorm differentiation and seedling growth in Dendrobium hybrid seed cultures as influenced by organic additives. J. Orchid Soc. India. 19. 67-70.

[14] Aktar, S., K.M. Nasiruddin, K. Hossain. 2008. Effects of different media and organic additives interaction on In Vitro regeneration of Dendrobium orchid. J. Agr. Rural Dev. 6. 69-74.

[15] Kaur, S., K.K. Bhutani, 2012. Organic growth supplement stimulants for in vitro multiplication of Cymbidium pendulum (Roxb.)sw. J. Hortic. Sci. (Prague). 39(1). 4752.

[16] Islam, O., M.S. Islam, M.A. Saleh. 2016. Effect of banana extract on growth and development of protocorm like bodies in Dendrobium sp. orchid. The Agriculturists. 13(1). 101.

[17] Untari, R., M.P. Dwi. 2006. Pengaruh bahan organik dan NAA terhadap pertumbuhan Anggrek Hitam (Coelogyne pandurata Lindl.) dalam kultur In Vitro. Jurnal Biodiversitas. 7(3). 344-348.

[18] Mulyanti, S. 2005. Teknologi pangan. Trubus Agri Sarana. Surabaya.

[19] Widiastoety, D., R.W. Prasetio, Purbadi. 2004. Pengaruh bubur buah pisang terhadap pertumbuhan planlet Anggrek Phalaenopsis dalam media kultur. Research 
and Development Center of Horticulture. Bogor.

[20] Djajanegara, I. 2010. Pemanfaatan limbah pisang dan air kelapa sebagai bahan media kultur jaringan Anggrek Bulan ( $P$. amabilis) Tipe 229. Jurnal Tenik Lingikungan. 11(3).373-380.

[21] Agriani, E.B. 2010. Pengaruh penambahan berbagai ekstrak pisang pada media Vacin and Went (VW) terhadap pertumbuhan Anggrek Cymbidium traceyanum yang ditanam secara In Vitro. Bachelor Thesis. Faculty of Siences and Technology. Islamic State University of Alauddin. Makassar.

[22] Nabors, M.W., S.K. Catherine, D.M. McHugh. 1982. Green spots are predictors of high callus growth rates and shoot formation in normal and in salt stressed tissue cultures of Oat (Avena sativa L.). Zeitschrift für Pflanzenphysiologie. 105(4). 341-349.

[23] Ben Amer, I.M., A. Börner. 1997. Plant cell, tissue and organ culture. Available at: https://doi.org/10.1023/A:1005855912655.

[24] Khalifah, R.A. 1966. Indolyl-3-acetic acid from the developing banana. Nature. 212. 1471-1472.

[25] Arditti, J. 1968. Germination and growth of orchids on banana fruit tissue and some of its extracts. Am. Orchid Soc. Bull. 37. 112116.

[26] Widiastoety, F.A. Bahar. 1995. Pengaruh berbagai sumber dan Kadar karbohidrat terhadap plantlet anggrek Dendrobium. Jurnal Hortikultura. 5(3). 76-80.

[27] Al-Khateeb, A.A. 2008. Regulation of In Vitro bud formation of date palm (Phoenix dactylifera L.) cv. Khanezi by different carbon sources. Bioresour. Technol. 99(14). 6550-6555.

[28] Praveena C., C. Veeresham. 2014. Multiple shoot regeneration and effect of sugars on growth and nitidine accumulation in shoot cultures of Toddalia asiatica. Pharmacogn. Mag. 10(Suppl 3). S480-S486.

[29] Sheeba, E., S. Palanivel, S. Parvathi. 2015. In vitro flowering and rapid propagation of Physalis Minima Linn. - a medicinal plant. Int. J. Innov. Res. Sci. Eng. Technol. 4(1). 18763-18768.

[30] Salisbury, F.B. \& C.W. Ross. 1995. Perkembangan Tumbuhan dan Fisiologi Jilid III. ITB. ITB Press. Bandung.

[31] Kaity A., A.M. Parisi, S.E. Ashmore, R.A. Drew. 2009. Root initiation and acclimatization of papaya plants. Acta Hortic. 812. 387-394.

[32] Scanlon, M.J. 2003. The polar auxin transport inhibitor N-1-Naphthylphthalamic acid disrupts leaf initiation, KNOX protein regulation, and formation of leaf margins in Maize. Plant Physiol. 133(2). 597-605.

[33] Keller, C.P., R. Stahlberg, L.S. Barkawi, J.D. Cohen. 2004. Long-term inhibition by auxin of leaf blade expansion in bean and arabidopsis. Plant Physiol. 134(3). 12171226.

[34] Utami, P.K, B. Ginting, A. Santi. 2011. Pengaruh bahan organik terhadap pertumbuhan planlet Anggrek Dendrobium secara In Vitro. Proceeding of National Seminar on Floriculture. Research Center of Ornamental Plants. Cianjur.

[35] Utami, E.S.W., S. Hariyanto, Y.S.W. Manuhara. 2017. In Vitro propagation of the endangered medicinal orchid, Dendrobium lasianthera J.J.Sm through mature seed culture. Asian Pac. J. Trop. Biomed. 7(5). 406-410.

[36] Jainol, J.E., A.G. Jualang. 2015. In Vitro shoot multiplication and rooting of shoot tip explants of dimorphorchis lowii: an endemic orchid of Borneo. J. Trop. Plant Physiol. 7. 14-25.

[37] Overvoorde P., H. Fukaki, T. Beeckman. 2010. Auxin control of root development. Cold Spring Harb. Perspect. Biol. 2(6). a001537.

[38] Chen, X., Y. Qu, L. Sheng, J. Liu, H. Huang, L. Xu. 2014. A simple method suitable to study de novo root organogenesis. Front Plant Sci. 5. 208.

[39] Liu, J., L. Sheng, Y. Xu, J. Li, Z. Yang, H. Huang, L. Xu. 2014. WOX11 and 12 are involved in the first-step cell fate transition during de novo root organogenesis in Arabidopsis. Plant Cell. 26. 1081-1093.

[40] Nowak, J., K. Pruski. 2002. Priming tissue cultured propagulesin: Low cost options for tissue culture technology in developing countries. Proceedings of a Technical Meeting organized by the Joint FAO/IAEA Division of Nuclear Techniques in Food and Agriculture. Vienna. 68-81.

[41] da Silvaa, J.A.T., M.M. Hossain, M. Sharma, J. Dobránszki, J.C. Cardoso, Z. Songjun. 2017. Acclimatization of In Vitro-derived Dendrobium. Hortic. Plant J. 3(3). 110-124. 